\title{
Orthodoxy, Renewal and Complexity in Contemporary Economics
}

The nature of mainstream orthodoxy in contemporary economics is proliferating social and academic disillusionment with what the profession managed to deliver in terms of "useful knowledge", particularly in pre-empting and later managing the ongoing financial crisis. The neoclassical paradigm, however, is by now facing challenges both from the natural sciences and economic research projects influenced by those. At this point, there is room for paradigmatic as well as incremental changes in the discipline; the latter is already in the making. ${ }^{1}$

Der orthodoxe Mainstream der heutigen Wirtschaftswissenschaften enttäuscht Gesellschaft und den akademischen Bereich hinsichtlich des Bestandes an „nützlichem Wissen “, insbesondere mit Blick auf die Vermeidung und das Management der gegenwärtigen Finanzkrise. Allerdings wird das neoklassische Paradigma inzwischen auch seitens der Naturwissenschaften und durch sie beeinflusste ökonomischen Forschungsagenden herausgefordert. Insofern besteht eine interessante Möglichkeit zu paradigmatischer wie inkrementeller Veränderung der Disziplin; in Ansätzen ist dies bereits heute erkennbar.

This contribution attempts at providing an explanation for how economics with its peculiar methodology of analysis and focus on modelling emerged. It furthermore tries to answer the intriguing question, haunting the discipline over the past 150 years or so, namely if, and to what degree analytical methods, that have been developed in and for the natural sciences, are apt for application in a different field. For the latter purpose, some of the fundamental issues of philosophy of science have to be addressed, such as the uses and misuses of reductionism and equilibrium analysis. The rather fundamental changes that have emerged in the natural sciences since the onset of neoclassical analysis are concerned as well. The basic endeavour is an attempt to re-establish the match between the methodology of economics and the natural sciences.

1 This contribution is based on the monograph Csaba, L.: Crisis in Economics?, Budapest, 2009, forthcoming. 
To be sure, no science can exist without methodology. Still, it is necessary to provide justifications for the question whether or not methods developed in one discipline should be transplanted to another one. In the case of economics, this has never been the case. With the exception of quibbles of some major personalities, as the most prominent visitor to our field, John von Neumann, who is known to have advocated reliance on a single analytical method across each of the disciplines, this choice has traditionally been a contested one. Notwithstanding the controversy, with the passage of time economics has developed into a mathematical discipline, where formalisation, at least in the mainstream journals, dominates all other considerations.

The following shall not, by any means, be read as an anti-formalist manifesto. However the current financial crisis has multiplied calls for soul searching. Namely, to what extent progress in economics has equipped us to master real world challenges, and to do so in a superior manner than our ancestors could. Judging by the output of major quality papers and increasingly also in leading journals, this has not always been the case. The hypothesis to be tested is that these shortcomings are not unrelated to the self-interpretation of the discipline. We may join Alan Blinder, one of the most influential academics and practitioners in claiming that the past few decades have produced relatively little "useful knowledge". ${ }^{2}$ Moreover, some of the regulatory and policy mistakes may also be related to the blind and undifferentiated application of abstract economic insights.

Econometrics, statistics and reliance on analytical techniques borrowed from mathematics have long been integral parts of the economics discipline. Thus tradition and substance alike allows appreciating these tendencies on their own right. What is puzzling is something different: the growing pre-eminence of methodological exclusionism, meaning the tyranny of one and sole approach, i. e. developed by the neo-classical school and subsequently integrated in both the new classical and neo-Keynesian schools. Thus I do not analyse that part of professional output which is devoted, by its nature, to the traditional research fields, as e.g. the output in Econometrica, Applied Economics, Journal of Econometrics or various journals of statistics, which in most countries count among the eldest and thus most prestigious fora of the profession. The focus shall be on the output of defining journals of the field. These have taken over increasingly the traditional role of monographs in deciding what is considered to

2 Blinder, A.: Economics Becomes a Science - or does it?, in: Bearn, A. (ed.): Useful Knowledge, Philadelphia, 1999, 141-154. 
be the crème de la crème in the profession - the latter development itself reflecting the deliberate tendency to emulate natural sciences in general and physics in particular.

In the second half of the twentieth century, formalised economics has become the name of the game, crowding out all the previously competing paradigms as that of the Austrian school, institutionalism, structuralism and various heterodox approaches. In the mainstream of economics, the ambition of post-war decades has been to match physics in terms of exactness and also in terms of expression. The major idea has been to be able to "put numbers on variables" and establish quantitative relationships among those. A mere glimpse on the output of major journals of the field, from The American Economic Review to The Economic Journal, allows us to observe this state of affairs. This would by no means be a cause for concern, if other established criteria of sciences, such as primacy and originality of the insight, testing theoretical propositions on empirical grounds, or the applicability/wider social relevance of any finding, would not be entirely or frequently missing. For instance few would doubt that in pharmaceutical chemistry the success of a new molecule can be judged on its ability to cure illnesses that could not be cured before, or to cure an illness with less side-effects and lower costs than before. Similar feedbacks are usually being rejected out of hand in the case of a large part of the output produced in top-ranked journals.

In terms of academic promotion, especially in major universities, the breakthrough has been perhaps even more straightforward, while very few articles that deserve the name political economy in any sense have been brought by the Journal of Political Economy over the past quarter of a century. The quibble of American students qualifying economics as "advanced math in disguise" is perhaps true. In recent times, even wilder advances are being made, further narrowing the field. In the latter line several PhDs, especially in Chicago, are produced in the current decade as "computational economics", relying exclusively on ever more sophisticated computer techniques as their major feature. ${ }^{3}$ This seems to be the trend-setter in terms of academic appreciation, publishing in top journals, and academic promotion alike.

3 Cf. also Zalai, E.: The von Neumann Model and Early Models of General Equilibrium, in: Acta Oeconomica, 54/1 (2004), 3-38. 


\section{The Emergence of the Methodological Bias}

It would be difficult to dispute the finding of the broad survey by William Baumol that the quest for rigor in economics has clearly become dominant over the traditional quest for social relevance. ${ }^{4}$ Academic economics, as it has evolved in the past few decades, is generally deeply suspicious of any policy applications. The mood of many departments is openly hostile to business practice - as distinct from microeconomics -, let alone the other "soft" social sciences. In a number of ways, economics seems to have lost its interest in time and the historic context. Some go as far as declaring economics as a mere methodology devoid of a peculiar subject of its own. ${ }^{5}$ The pioneer of this approach - termed sometimes as economic imperialism - has undoubtedly been Gary Becker, who was awarded the Nobel Prize "for having extended the domain of microeconomic analysis to a wide range of human behaviour and interaction, including nonmarket behaviour ${ }^{\prime 6}$ such as discrimination against minorities, crime, education and fertility.

Explaining his point, Becker goes out of his way in stressing that "unlike Marxian analysis, the economic approach I refer to does not assume that individuals are motivated solely by selfishness or gain. It is a method of analysis, not an assumption about particular motivations. The analysis assumes that individuals maximize their welfare as they conceive it." In short, this is the extension of the microeconomic approach and its arsenal of analysis to all walks of life. Similarly, other formative personalities have also characterised the mainstream as the manifestation of the modelling approach, applied to any aspect of economic life. ${ }^{8}$ In this respect, the 2005-2009 proceedings of the annual conferences of the American Economic Association - published as a special issue of American Economic Review each respective year - may well mark the dawn of a new era, with real world related issues, such as the labour market or the EMU, coming back to the main stage of formal macroeconomic analyses. But in the majority of the mainstream journals, the nuances of modelling techniques and the way the

4 Baumol, $W$ : What Marshall Didn't Know: the Contribution of XXth Century to Economics, in: Quarterly Journal of Economics, 115/1 (2000), 1-44.

5 This approach originates in Pareto, however it has by no means been dominant until the 1980s.

6 The Nobel Foundation: The Sveriges Riksbank Prize in Economic Sciences in Memory of Alfred Nobel 1992, http://nobelprize.org/nobel_prizes/economics/laureates/1992/, author's emphasis.

7 Becker, G.: The Economic Way of Looking at Life. Nobel Lecture, 09.12.1992, online at http:// nobelprize.org/nobel_prizes/economics/laureates/1992/becker-lecture.pdf, 1 .

8 Solow, R.: How Did Economics Get that Way and What Way Is It?, in: Daedalus, 126/1 (1997), 39-58. 
issue is being formulated still matters far more for acceptance for publication than any substantive question, be that of social or business relevance, implications for other disciplines, or simply novelty of insights.

Gary Becker ${ }^{9}$, who is currently a holder of a joint appointment to the Department of Economics and the Department of Sociology in the University of Chicago, also complains bitterly in his autobiography ${ }^{10}$, that his focus on reality-related issues and the instrumental use of mathematics had been seen for decades by his peers in the AEA as beyond the limits of the profession - true more before than after his Nobel Prize in 1992. But as so often, the mainstream proved to be flexible enough to incorporate what seemed revolutionary or deviant, even positively hostile to it at a certain point. In reality, according to the self-evaluation of Becker, the major oeuvre is the application of the modelling approach offering microeconomic foundations for the understanding of choices in the intimate sphere of human beings - phenomena, which are normally viewed as being the farthest from wealth-maximising, at least in normative terms. ${ }^{11}$

In a way, this line of development may qualify as the adolescence of a relatively young academic discipline. The parallel to human development is rather obvious. This stage is characterised by the distancing of the new individual from her origins, from her previously natural environment. Under such angle the sometimes excessive emphasis on methodological rigor is, in the long run, perhaps an inevitable in-between station on the road to cooperation, based on more self-confidence. It is illuminating in this respect to delineate two concepts: mainstream and orthodoxy. ${ }^{12}$

The first is a sociologically determined category of those individuals and departments that dominate the profession at any given point of time, and therefore exhibit - perhaps inevitably - a considerable degree of diversity in terms of acceptable views and approaches. By contrast, the second is an intellectual category, which is a static representation of a dynamic and constantly changing profession. The first is often represented by the second, although more in textbooks than in the profession in toto. Still, as the above cited overview notes, it is exactly the methodologically hard core of economics, which tends to resist the

9 Cf. Becker, G.: The Economic Approach to Human Behavior, Chicago, 1976.

10 Id:: Autobiography, online at http://home.uchicago.edu/ gbecker/biography/biography.html.

11 Becker, G.: A Treatise on the Family, Cambridge, MA, 1991.

12 Colander, D./Holt, T./Rosser, B.: The Changing Face of Mainstream Economics, in: Review of Political Economy, 16/4 (2003), 485-494, here 490-493. 
challenges offered by ecological, experimental, behavioural, psychological, evolutionary approaches as well as advances in statistics, which highlight the limitations of empirical proof through classical methods.

What may induce us to think that the future of economic analysis is likely to witness a return to the broad church of the social sciences, while also sustaining its self-declared aim, the classical Walrasian agenda of being "just like the natural sciences"? For the time being, most mainstream departments would hesitate at best to accept the label of being a constituent of the social sciences. This can be partly explained by the different analytical paradigms and the methodological softness, which is accepted by many departments in other fields such as international relations or sociology. However, the major explanatory variable is not the spread of post-modernist, post-structuralist, non-rationalist schools in the latter disciplines, but rather the self-selection in the field of global economics as we shall illustrate below.

In a debate a few years ago in what has perhaps been the most original continental journal of the profession, the Swiss Kyklos documented the existence of "black holes in economics", ${ }^{13}$ which refers to the fact that about three fourths of the papers published in the leading journals do not trigger any controversy, not even a single citation. This was considered as a clear sign of social irrelevance or waste of public resources -, since findings of any sort usually do trigger debates, be that on the "facts and figures", the interpretation of the evidence or merely further reflections on the subject matter. Such debates tend to be excluded by the preponderance of modern econometric analyses, where the focus is nearly exclusively on the proper specification of the model and the appropriate use of mathematical techniques, while references to any broader implications are usually rejected from the very outset. ${ }^{14}$

As the scientometric analysis of the select mainstream academic journals by $E$. Han Kim et al. has indicated, among the most frequently cited works macroeconomic issues and real world phenomena in general are losing ground. ${ }^{15}$ The deci-

14 Alternatively, the subject matter is such that it already renders the traditional quest for broader social implications irrelevant. Examples for the latter from among the leading journals in recent periods include Thompson, W.: Children Crying at Birthday Party. Why?, in: Economic Theory, $31 / 3$ (2007), 501-522 or Tao H.L.: Attractive Physical Appearance vs Good Academic Characteristics: Which Generates More Earnings?, in: Kyklos, 61/1 (2008), 114-133.

15 Han Kim, E./Morse, A./Zingales, L.: What Has Mattered to Economics Since 1970?, in: Journal of Economic Perspectives, 20/4 (2006), 198-202. 
sive factor of academic appreciation - in terms of publishing, rather than citation or other forms of conventional utilisation - seems to be various micro issues, and above all methodology, not the subject matter - such as financial crises - or the practical relevance of the finding for policy or business. In his survey on the development of macroeconomics over the past few decades, Gregory Mankiw also finds that the predominant academic trend "has become more interested in developing analytical tools and establishing theoretical principles. These tools and principles, however, have been slow to find their way into application"16. This is all the more paradoxical, since the practical-instrumental orientation of economics as a discipline seems to have been beyond doubt, at least up until the last two decades. ${ }^{17}$

But how has the profession got to this stage? To sum up briefly the extensive summaries cited in this piece, a number of factors may be mentioned. Let us note that the pre-eminence of the current technicist orthodoxy became a predominant trend in Britain already in the 1890-1920 period. This happened to a large degree through building up power positions in the leading universities and journals, with the ascend of Keynesianism only slowing down, but by no means reverting the tide. ${ }^{18}$ Subsequently, by the 1970 s, it had become step by step the feature of top American schools ${ }^{19}$, with their continental European counterparts following suit with much less speed and with a delay of 20-25 years by the 1990s only. By contrast, in Central and Eastern Europe the intellectual battleground is by and large still open, with a pluralism of approaches still being demonstrable in all major universities. In Hungary for instance, both the internationally used intermediate level textbook ${ }^{20}$ and the domestic graduate school textbook ${ }^{21}$ emphasise

16 Mankiw, G.: The Macroeconomist as a Scientist and Engineer, in: Journal of Economic Perspectives, 20/4 (2006), 29-46, here 29.

17 In his posthumously published Nobel Lecture, one of the two first award winners, Ragnar Frisch, observed: "At the global level the good economic theory is to lay bare the way in which different economic factors act and interact on each other in a highly complex system, and to this in such a way, that the results may be used in practice to carry out the most efficient way, specific desiderata in the steering of the economy" (Frisch, R.: From Utopian Theory to Practical Applications: the Case of Econometrics. Nobel Lecture, in: American Economic Review, 72/6 (1981): 1-16, here 6.

18 Deane, P.: The Scope and Method of Economic Science, in: The Economic Journal, 93/369 (1983), 112.

19 Until the late 1940s, the influence of John Commons, Thorsten Veblen and in particular Wesley Mitchell ensured the dominance of various institutionalist streams in the US academia, while the 195070 period can be regarded as the transitory stage with its methodological pluralism.

20 Varian, H.: Mikroökonómia középfokon [Intermediary microeconomics], Budapest, 2003, Ch. XXIII.

21 Zalai, E.: Matematikai közgazdaságtan [Mathematical economics], Budapest, 2001, 7. 
the instrumental nature of applying formal tools to streamline argumentation and ensure the coherence of the argument. But this is motherhood and apple pie, rather than the triumph of methodological exclusionism we tried to document for the leading journals and schools.

In a way typical of the mainstream, a defining figure of the area, both as a textbook author and as a prolific and frequently cited analyst, IMF Chief Economist Olivier Blanchard, in his stimulating and insightful tour d'horizon of the ups and downs of the profession, axiomatically excludes growth theory and the political economy of growth from the subject from the very outset. ${ }^{22}$ Although this weighty choice pre-determines much of the outcome of his analysis, he does not even attempt to justify it. Given his personal impressions from advising governments and central banks in "Eastern Europe" in his concluding remarks, he observes that radical changes in institutions may perhaps be included as a modifying factor in the analysis; this three-line observation however does not change at the slightest his overall picture of what the hard core of the profession is, and how it should evolve.

The change of citation practices and the unparalleled geographical concentration of Nobel Prizes signal the growing pre-eminence of the US academia in global economic research, which counts as cutting edge. It would be hard to find authors, decorated with the Prize, who would not either be US citizens or have spent their prime academic time at leading US universities. ${ }^{23}$ This implies inter alia that controversies which already seemed to had been settled in one way or another in Europe, such as the dissimilarity of social and natural processes and the analytical tools fitting these, ${ }^{24}$ resurfaced in the post-war New World. And what happened in America later became the trend-setter for the rest of the globe. All the more so, as "peripheral" countries often launched educational programmes which aimed at copying US curricula and patterns while outsourcing

22 Blanchard, O.: What Do we Know About Macroeconomics that Fisher and Wicksell Did not Know?, in: Quarterly Journal of Economics, 115/4 (2000), 1375-1409.

23 Perhaps Leonid Kantorovich, Reinhard Selten, Jan Tinbergen and Sir John Hicks are the few exceptions. Non-American Nobel winners, like Amartya Sen, Maurice Allais, Daniel Kahneman or Trygve Haavelmo have spent several years in the US and have long been integral parts of the US academia before receiving the award.

24 Röpke, W.: The Social Crisis of Our Time, New Brunswick, NJ, 1992 (first published 1942); Hayek, F.A.: The Counter-Revolution of Science. Studies on the Abuse of Reason, Indianapolis, 1979 (first published 1952). 
much of their $\mathrm{PhD}$ education and other truly innovative research to the "lonely hegemon". ${ }^{25}$

\section{Reasons for and Steps in Technicisation}

In the United States as well as in Britain, the breakthrough of the current mainstream orthodoxy in terms of funding and recruitment was due to the needs of managing the Great Depression and later the war economy. This concern remained dominant during the entire period of existence of the bipolar world, emptying the pure science departments in all but the wealthiest universities. Flocks of scientists were hired for the needs of the military and the state administration. Thus formalised and quantitative orientation had increasingly become a must.

True, mathematical economics is also firmly rooted in continental economics, as the examples of Cournot, Dupuit, Walras and Pareto, as well as the British Edgeworth exemplifies. Econometrics too, has been developed, to a large degree by Europeans, such as Koopmans, Haavelmo and Tinbergen. However, as the excellent monographic summaries by Zalai $^{26}$ and more recently and more indepth by Móczár $^{27}$ have documented extensively, these isolated initiatives could produce a breakthrough only through the workings of the Cowles Commission in the USA. Likewise the formalisation as practiced by Debreu, and influenced largely by internal developments in mathematics rather than in economic processes or policies, has become formative owing to the powerful support of Samuelson and Arrow in shaping graduate and postgraduate level curricula in the United States during the 1950s and the 1960s.

We should by no means forget that the needs of the space programmes and the nuclear industry exerted a dominant influence on priority funding for several decades after World War II. The impact of the broader Zeitgeist, which called for more nationalisation and planning, cannot be overlooked either. The high academic standing of formalised approaches was well represented by the Nobel Prizes of Tinbergen, Frisch, Kooopmans, Kantorovich and of course Samuelson. Gradually, the contemporary refinements of Keynesianism had also become open to formalisation.

This is neatly documented in Bourgignon, F./Elkana, Y/Pleskovic, B. (eds.): Capacity Building in Economics Education and Research, Washington, DC, 2007.

26 Zalai, E.: Matematikai közgazdaságtan, op. cit.

27 Móczár, J.: Fejezetek a modern közgazdaságtudományból [Chapters from Contemporary Economics], Budapest, 2008. 
However it was a tall order. John Maynard Keynes never emphasised the need for formalisation, not even to the degree Alfred Marshall used to, who is known to have used geometrics and algebra as a form of shorthand - which can never replace theory as such. ${ }^{28}$ His successor in Cambridge, Nicky Kaldor, was actually in the forefront of fighting the neoclassicals. ${ }^{29}$ The founding fathers of growth theory and of panel analysis, such as Domar, Bergson, Chenery and Kuznets, also took it for granted that the ever more complex econometrics of their analysis is a tool, rather the objective, let alone the very theory itself. Browsing through the post-war book review and book notes sections of major journals, from the Journal of Economic Literature to the Economic Journal, we find a minor, though impressively growing section of contributions of neoclassical orthodoxy featuring as just one stream in the overall output. ${ }^{30}$ And not until the mid-1980s do we find that these become pre-eminent, occupying the place of economic theory as such gradually in all major textbooks ${ }^{31}$ and journals, starting with the Journal of Political Economy of Chicago and the American Economic Review, both former outposts of methodological and theoretical pluralism. Let us recall the fact, even though it might sound odd for the younger generation, that up until the 1970s, the United States was by no means recognised as the universal trendsetter, especially not in intellectual fields and fashions like classical music, visual arts or philosophy. In his Road to Serfdom, written during World War II for British intellectuals, the then LSE professor Hayek speaks as trivial about Britain being an unconditional importer of - basically continental, often German - ideas

28 Recall his fourth, proverbial dictum among his six commandments: "if you can not put it in plain English, forget about the mathematics."

29 Kaldor, N.: Economics without Equilibrium, Armonk, NY, 1985.

30 It is worth noting that until the late 1980 s both the $J E L$ and the JPE regularly carried reviews of academic output published in German, Italian and French or in English by non-US publishers. This practice was discontinued and neither $A E R$ nor $J P E$ publishes reviews any longer. References to any nonUS output have dramatically dropped in all the leading journals. It is also telling that in mainstreamoriented area studies journals, such as the Economics of Transition, the Journal of Comparative Economics, the Journal of Development Economics or the Economic Systems, reliance on primary sources ceased to be a prerequisite for publishability, while methodological eloquence is decisive.

31 It is worth recalling that the 1985 textbook of Edmund Phelps, which is over 620 pages long, is entitled Political Economy. Phelps himself, in his lengthy Nobel autobiography considers this as a major piece. His pet project of the 1990s was a political economy course at Yale on what moved the changes in the 20th century. But others, such as the more conventionally used Samuelson-Nordhaus textbook (Samuleson, P.A./Nordhaus, W.D.: Economics, $16^{\text {th }}$ ed., Boston, 1998), even in its $16^{\text {th }}$ English language edition, is not methodologically overburdened either. 
since the $1870 \mathrm{~s},{ }^{32}$ or of the then universal perception of Germany being "at the height of universal civilization",33 or even as a pioneer in social engineering, a model to be emulated for many if not most ${ }^{34}$ - claims that are richly documented by citations.

There is thus nothing less trivial than explaining the earthquake-like, truly epochal change in the discipline. In order to explain this puzzle we should consider the broader social context, including the lack of major fluctuations and crises in the post World War II period, the flourishing of the welfare state, the technological revolution - exemplified by computers and the Sputnik -, as well as the eradication of mass poverty in advanced countries. Keynes is known to have understood his theory as economics of crisis and its management, which were by then gone. But in a much broader sense by the 1960s and 70s, the spread of blind faith in technology and its inherent capabilities for solving each and every human problem had created a fertile soil for quantitative approaches, which seemed irrefutably scientific producing evidence and results.

In the meantime the emerging post-colonial states, with their left wing governments flirting with planning, and seeking for non-capitalist ways of economic management based on what is by now the old developmental paradigm, also created a massive demand for persons versed in planning and programming techniques. In the communist economies, the reliance on planning required an army of appropriately trained specialists, even though mathematical methods in optimal planning, as advocated first in the US of the 1930s by Oskar Lange and Abba Lerner, joining the pioneering work by Novozhilov and Feldman in the 1920s, later followed in the 1960s and 70s by the Novosibirsk school and the Central Economic Mathematical Institute (TSEMI - the famous institute where Markov was active) had never become more than an instrumental additional reference point. ${ }^{35}$ In reality command planning based on material balances and

32 Hayek, F.A.: The Road to Serfdom. London, 2007 (first published 1944), 46-48 (pages cited according to the "definitive" edition by University of Chicago Press).

33 Ibid., $77 \mathrm{f}$.

34 Ibid., 179 and Ch. 13.

35 For a summary of the calculation debate, see Hayek, F. A.: Socialist Calculation: the "Competitive" Solution (1940), in: id.: Individualism and Economic Order, Chicago, 1948, 181-208 as well as Nove, A./Nuti, M.D. (eds.): Socialist Planning-Selected Readings, Sidney et al., 1972. 
quantitative targeting prevailed, as control of the Party over details could not be given up. ${ }^{36}$

It is hardly by chance that the above trend triggered a series of reactions, mostly from individuals of high personal standing and reputation. Besides the already mentioned old Keynesians, the then institutionally and intellectually strong Marxists, the developmentalists, the disequilibrium school, self-declared "trespassers" like Albert Hirschman and John Kenneth Galbraith as well as various institutionalists, who still dominated everywhere except in the US schools, all attacked the irreversible. Criticism seems to have come from all corners. Lord Thomas Balogh, a long-time advisor of Labour Governments and a leading Oxford intellectual, subjected both emerging major lines, i.e. monetarism and equilibrium economics, to devastating critique for being theoretically irrelevant and positively harmful in terms of policy advice. ${ }^{37}$

Critics also emerged from the traditional right, represented by the Austrian school, sounding identical concerns. Ludwig von Mises called into question the entire rationale of formalisation, when he stressed that economic processes are outcomes of a multitude of human actions. ${ }^{38}$ As long as the latter are inherently uncertain and thus probabilistic, can be adequately formalized and predicted through quantitative methods. Friedrich August von Hayek devoted his Nobel lecture to explaining the difference between real insights and the pretence of knowledge provided by formal analyses. He also convincingly showed how the Walrasian project, executed to its extreme, had been at the root of policy failures, which translated into stagflation all over the advanced market economies. ${ }^{39}$ However these cautioning words were usually neglected, even ridiculed at the time. Likewise the valid contemporary analysis of János Kornai on the trade-off between elegance and relevance ${ }^{40}$ was mostly shrugged off, as indicated by the rather cool reception of the book by the dominant schools.

The belief that the future was basically subject to human shaping was predominant, and transnational corporations and state-controlled models of economic

Why it was an inherent feature rather than a policy mistake was only partially understood by contemporaries, which is explained and proven ex post by Kornai, J.: The Socialist System: Political Economy of Communism, Oxford, 1992, chapters 21, 22 and 24.

37 Balogh, T.: The Irrelevance of Conventional Economics, London, 1982.

38 Mises, L.v.: Epistemological Problems of Economics, New York, 1978.

39 Hayek, F.A.: The Pretence of Knowledge. Nobel Lecture, 11.12.1974, online at http://nobelprize.org/ nobel_prizes/economics/laureates/1974/hayek-lecture.html.

Kornai, J.: Anti-Equilibrium, Amsterdam, 1971. 
management relied equally heavily on planning and programming. It was not until the epochal changes in the post-1973 and post-1979 period that the way was paved for more reflective, probabilistic and less pretentious approaches in the economics discipline. The stagflation of the 1970s, the international financial crises in 1982 and 1987, the largely unforeseen collapse of the Soviet Empire in 1989/91 and the similarly unanticipated 1997-99 financial crises and contagion all contributed to this development.

Although mathematical approaches were often seen by their traditional adversaries as "natural allies" to planning mentality, in reality these - especially general equilibrium thinking - are institutionally neutral. ${ }^{41}$ Consequently, it did not require a major twist from the profession to re-emphasise its inherent commitment to the market and the competitive solution during the neo-liberal ideological turn of the 1980s and 90s. At the same time the new Keynesians could also easily turn the analytical arsenal to their own use. It is worth noting that truly committed and ideological liberals, such as Friedman, Buchanan and Hayek, had never gone out of their way to offer formalised proofs for their ideas. By contrast, formalists, focusing first and foremost on "science appeal", include staunch free market believers as Robert Lucas, and market sceptics such as Joseph Stiglitz. Formalism and ideological commitment thus remain two different cups of tea. ${ }^{42}$

The low level of institutionalisation of the various and competing institutionalist approaches versus the high level of academic embeddedness of the formalist approaches, especially in the US, can be seen as another important factor in the breakthrough of the orthodox interpretation of mainstream economics. David Colander and Harry Landreth emphasise the importance of the ability to institutionalise and hand down the creed from mentor to disciple ${ }^{43}-\mathrm{a}$ trait that has been conspicuously missing from the diverse heterodox approaches. They also highlight the usefulness of relatively straightforward organising principles and

41 Briefly this means that similar outcomes are conceivable under centralised and competitive institutional arrangements since those are being either presupposed or abstracted away in the modelling process.

42 Meanwhile in his Nobel autobiography, which also provides an overall assessment of the state of the profession, Edmund Phelps rightly notes that the real dividing line since around 1980 does not lie between neo-keynesians and new classicals, since both are commited to formalisation and thus open to a quasi-merger (Phelps, E.: Becoming an Economist: From Early Preparation to my New Direction, 2006, online at http://nobelprize.org/nobel_prizes/economics/laureates/2006/phelps-autobio.html) - a point also noted by Blanchard, O., op. cit. Rather the fundamental drift exists between these two and the various followers of the Austrian tradition, who never conceptualised the macroeconomy as an engine, liable to precise quantitative interpretation.

43 Colander, D./Landreth, H.: Pluralism, formalism and American economics. Middlebury College Economics Discussion Paper, no. 04-09, 2004, 5-10. 
potential for testing student output, which are readily offered by neoclassical orthodoxy, for the needs of masses of economics students in the expanding graduate programmes. This is contrasted to the interest in nuances and controversy in the best few $\mathrm{PhD}$ seminars of truly good schools. The criticism of exclusivity and reign of formalism, as offered by the various traditionalists cited above, was seen as institutionally marginal, socially elitist, too philosophical in methodology, and first and foremost too hard to adapt to the needs of an average school with average students/teachers, who are confronted with an academic market that requires standardisation for most of the output. In other words: economies of scale matter for the academic market as well. Furthermore, the heterodox approaches, while being eloquent on critique, have failed to come up with viable alternatives, not only in theory but also at the policy-making level. ${ }^{44}$ This is partly due to the fact that differences across the various heterodox schools can and often tend to be bigger than the drift that exist for instance between neo-institutionalists and the faction of modern mainstream, which integrates pieces of institutional insights - such as Lopez-de-Silanes, Djankov or LaPorta. Being non-mainstream is unlikely to unify, say followers of Hayek and Marx. And being non-mainstream is also no guarantee for being original and sophisticated, in fact very often just the contrary is the case - as sometimes not even the methodological common ground and the needed technical elaboration is available.

While this is perhaps a valid description of the overall trend, important qualifications are due. Actual advancement of science is only very partially captured by academic promotion and other forms of contemporary appreciation by the public, even through (cross-)referencing methods. For instance, among the Nobel Prize Laureates, who also represent the defining, school-molding personalities of economics, we find many, who have not followed suit, such as S. Kuznets, $H$. Simon, F.A. von Hayek, G. Myrdal, M. Friedman, Th. Schulz, J. Buchanan, D. Kahneman, R. Fogel, D. North and A. Sen. Also from among other school-molding personalities whose overall references are literally countless, we find several "outliers". These authors include L. von Mises, W. Eucken, N. Kaldor, P. Bauer, A. Hirschman, J. Kornai, T. N. Srinivasan, P. Collier, V. Vanberg, A. Krueger, L. Yeager, J. Bhagwati, M. Todaro, I. Kirzner to mention only some of those whose 967. 
influence on the overall evolution of the profession must be beyond doubt to any impartial observer.

What may then explain the sustained disregard of reality $?^{45}$ This feature is certainly present in the bulk of academic output, even if individual top representatives of the guild, from Samuelson to Lucas, Tobin, Friedman and Becker, never refrained from contributing to policy debates in weeklies - as Newsweek and Business Week, and even daily papers, such as The Wall Street Journal or The New York Times. One factor might be fashion. Who would doubt that in all walks of life, from classical music to car production, it is an important issue ${ }^{46}$ Second, one may think about the aspiration of the guild to carbon copy physics, as the top science in the cold war period. ${ }^{47}$ Third, the influence of strong, impressive personalities as Samuelson, Solow or Lucas must be acknowledged. ${ }^{48}$

Fourth, one should not forget about the emergence of mass universities, a process, which took place first in the US then in Europe. In the latter case it followed the student riots of 1968 and the expansion of the welfare state in the West, while in the East pressures came from a democratising society in the post-1989 period. College and university enrolment rates went up from lower single digit percentages to over $40-45 \%$ for the cohorts of 18-30 year olds. One obvious way of managing masses is standardisation, routinisation and the application of objective screening criteria. ${ }^{49}$ Quantitative orientation may come rather handy, despite

45 This was aptly called by the late Lord Peter Bauer, who noted the rather palpable unfavourable consequences of indiscriminately applying these abstract academic insights for developing nations (Bauer, $P .:$ The Disregard of Reality, in: id.: From Subsistence to Exchange and Other Essays, Princeton, NJ, 2000, 15-27.

46 Thomas Kuhn identified aesthetics as a dominant criterion for the success of paradigms even in the natural sciences, that were to be emulated by economics (Kuhn, T.: The Structure of Scientific Revolutions, $2^{\text {nd }}$ ed., Chicago, 1970).

47 This is documented in a number of the overviews, which cite the role of the Cowles Commission and its aftermath. Mirowski goes perhaps the farthest in drawing this analogy providing a very critical account of this attempt (Mirowski, P.: More Heat than Light: Economics as Social Physics, Physics as Nature's Economics, Cambridge, 1989). See also the insightful comparison of Hands, D. W.: A Tale of two Mainstreams: Economics and the Philosophy of Natural Science in the mid-20th Century, in: Journal of the History of Economic Thought, 29/1 (2007), 1-13.

48 Likewise, the personality and the uncontested institutional dominance of Gustav von Schmoller in the 1882-1917 period in Berlin and the local academia ensured the exclusive role of the historical school, the contesting paradigm to early mainstream, in contemporary Germany. Only disciples of the latter line could achieve professorial appointments for several decades. Thus neo-classicals found themselves as marginalised in Germany and in culturally German oriented Central Europe as institutionalists and the followers of the historical school in Britain.

49 This is particularly highlighted in Colander, D./Landreth, H., op. cit., 8 with a basic line of thought in the theory of human capital/economics of education. 
its obvious shortcomings from the educational and employability/professional skill improving perspectives alike for the vast majority of students. ${ }^{50}$ Fifth, the role of conventions - or what we termed self-selection of the guild - is particularly important as explicitly stressed by Blanchard ${ }^{51}$, even if it is somewhat tautological. In a modification of this insight the Cambridge economist Bigo talks about the predominance of social games, focusing on power and based to a large degree on the psychology of the profession. ${ }^{52}$ Finally sixth, the distance from the field of application has long been a feature of the American academic economics profession, which is traditionally much less involved in advancing policy advice than its German, British or French counterparts. The sheer size of the US and its academia combined with the much more limited role of governmental intervention makes this distinction self-explanatory.

\section{Challenges to the Technicist Orthodoxy}

However, this state of art is becoming unsustainable for a number of reasons. First and foremost internal/inherent challenges, coming from within the sanctuary of the academia must be tackled. Advances in the natural sciences in general and within the discipline of physics in particular are posing major challenges. This relates both to the methodology and the epistemological foundations on which Newtonian physics and its emulation in mainstream economic modelling are built. Without wishing to intrude alien fields, let me cite authorities in the theory and history of physics, who explain the fundamental changes, which were brought about by the evolution of the two pillars of contemporary physics, quantum physics and the theory of relativity. ${ }^{53}$ These developments have several consequences. 1. Deterministic descriptions - where the predictive power is the basic strength and the quantifiable measure of success - have given way to probabilistic and stochastic approaches. 2. The method of measurement immediately influences outcomes and variables. ${ }^{54} 3$. Attempts at re-establishing any all-em-

Szentes, T.: A közgazdaságtan oktatása, avagy mit, miböl és hogyan (ne) oktassunk? [On Teaching Economics: What, How and From What Source Should (not) be Taught?], in: Köz-Gazdaság, 2/2 (2007), 141-170.

51 Blanchard, O., op. cit., point 2.4.

52 Bigo, $V$.: Explaining modern economics (as a microcosm of society), in: Cambridge Journal of Economics, 32/4 (2008), 527-554.

53 Cassidy, D.C.: Werner Heisenberg. American Institute of Physics, 2002, online at http://aip.org/ history/heisenberg/p01.htm.

54 This point is rightly invoked in a recent article by Török, who notes that results are crucially dependent on the statistical tools/concepts employed, while the latter reflect theoretical assumptions - often 
bracing, holistic theories along $19^{\text {th }}$ century lines have failed during the entire post World War II period. As an outcome of the conflicting interpretations of the novelties, "exact" quantitative measurements and thus exact predictions are now replaced by measuring the distribution of results with expected values and stochastic probabilities, while the measurement process itself is known to have prompt spillovers.

If the above holds, it would be hard not to see its implications for general equilibrium theory interpreted in a holistic fashion. General equilibrium thinking, derived directly from $19^{\text {th }}$ century physics, can hardly survive in other way than Newtonian physics, i. e. as being a mental model of regularising our ideas in the first run. But this would seem a very soft reading in the majority of mainstream departments, believing - though never proving - that only equilibrium situations lend themselves to comprehension and scientific analysis. As the leading authority put it, "macroeconomics today is solidly grounded in a general equilibrium structure" and for the future "one may hope for an integrated macro model based on only a few imperfections" ${ }^{, 5}$. However, as shall be illustrated later, it is not only physics, but a series of other natural sciences as well, where paradigmatic changes occurred during the $20^{\text {th }}$ century. If this is the case, those earthquakes can by no means leave economics untouched. This holds a fortiori for its methodology, irrespective of what role we attribute to it in the overall structure of the discipline as a whole.

From the "external" point of view different problems, mainly related to the application of insights, have emerged. To the general public as well as to most of the profession, mainstream economic analyses are becoming less and less accessible. This translates into low circulation and the previously cited low impact factor for the internally/professionally most highly esteemed platforms for publications. Meanwhile the traditional ally of economic analysis, the business elite exhibits less and less interest in the output of academic departments. This is becoming a problem, not only in terms of funding, but also in terms of social prestige. Some of the reasons for this development, as openly acknowledged by Nobel winner Robert Engle, decorated for his advances is business risk assessment, include:

implicit ones - that prejudge outcomes (Török, Á: A „Methodenstreit” és a magyar közgazdaságtudomány [The methodological debate and Hungarian economics], in: Magyar Tudomány, 168/12 (2007), 1520-1527, here $1523 \mathrm{f}$.

55 Blanchard, O., op. cit., 37. 
- Mathematical models rely on the same data/time series. Consequently, they act pro-cyclically, and support identical rather than competing/balancing options.

- The models can reflect and transmit only past evidence, while shocks/crises emerge at times and via means of fundamentally new factors, which become dominant in non-trivial and non-predictable manners.

- Real world situations tend to be both too complex and a mix of short- and long-term factors, in which not even scenario analysis can substitute for lack of transparency, which is yet another factor that is abstracted away in most of the models. ${ }^{56}$

For these reasons Engle, while sustaining his commitment to formal models, cautions decision-makers to make too much out of these, and rely on them in blind faith. ${ }^{57} \mathrm{He}$ also believes that the role for non-quantitative factors, such as intuition, remains vital for any viable microeconomic decision.

This line of argumentation was further advanced by Lord John Eatwell, ${ }^{58}$ one of the editors of the earlier version of the New Palgrave Dictionary of Economics published two decades ago. ${ }^{59}$ In his view the herd behaviour/bandwagoning of analysts, which was also described by Engle, exterminates the fundamental features of market coordination, i.e. the contrasting assessments of any situation owing to different levels of information, different mental models and expectations. Furthermore the focus on the microeconomics of finance only, both of the literature and of the regulator, leads to a false neglect of the macro. Namely that owing to its proclivity to crisis and contagion, the financial system is a prime case for economic activity with major externalities that call for regulation (by public authorities) in order to attain what is more than the sum of the priorities of the individual agents. Avoidance of systemic risk and the need for systemic sta-

Engle, R.F.: A Nobel díjas zseni is bukott a válságon [The Nobel Winner Genius Has Also Lost in Financial Crisis], interview granted in portfolio.hu, 28.08. 2007.

57 True, as the Deputy Governor of the National Bank of Hungary, Dr. Júlia Király reminded me, Engle did not receive his Nobel for his contribution to financial economics. Still, his insights remain valid. All the more so, as following the unmasking of major blurs in the financial modelling of Moody's by the FT, S+P voluntarily acknowledged similar major errors in its own modelling used for asset pricing (Financial Times of 14.06. 2008.

58 Eatwell, J.: Risk management and systemic risk, in: Estrin, S./Kolodko, G.W./Uvalic, M. (eds.): Transition and Beyond, Basingstoke/New York, 2007, 247-262.

59 The more recent and updated version appeared upon the publication of the Hungarian version of this analysis, as Durlauf, S./Blume, L. (eds.): The New Palgrave Dictionary of Economics, $2^{\text {nd }}$ ed., Basingstoke, 2008. 
bility are obvious cases to the point. This has rather immediate ramifications for Basle II, which emphasises autonomous risk management through VAR by each bank, furthermore it aims at enhancing transparency, thereby itself contributing to the reproduction of the ills. As good banks are disinterested in over-provisioning, bad banks might be tempted to doctor their books. In broader academic terms, one may become sceptical about the general relevance for the by now ritual quest for micro-foundations for any macro insight. ${ }^{60}$ In this respect the declaration about the "demise of macro" appears premature.

In a similar vein in a book published on the eve of the ongoing financial turmoil, Frydman and Goldberg also blamed the nature of modern economic research with its exclusive focus on the micro and obsession with "precise" predictions while neglecting additional sources of information - for the major misfit between high brow theoretical aspirations and dismal delivery in practice ${ }^{61}$ They contrast the continuously and recurrently false assessment of financial assets by analysts, who are trained mostly in mathematics and physics and who take their models at face value, with the practice of those relying on more mundane/backward sources of information, while assessing risks on physical assets. The latter includes examples such as the evaluation of the industrial "museums" like General Motors, as well as the empirical subject of their analysis, i. e exchange rate movements. Their common feature lies in the traditionally strong reliance on empirical/factual observation, long data series, historical memory and a number of rules of thumb, which are derived from decades of business experience rather than from any fashionable theory. While the latter by no means replace formal analyses, they complement it and thus yield superior results, whereas the "pure" modelling approach, which is cultivated and appreciated in academia, has proven to be of little avail. First and foremost it fails on its own terms, i. e. quantitative estimation and forecasting risks and returns. Let us recall: not only in terms of the big bank failures of the USA, such as Lehman Brothers or AIG insurance group, have projected and actual costs of consolidation differed by a factor of three. Also in such a trivial case as the bailout of Latvia in December 2008, the projected costs of $1.5 \mathrm{bn}$ US $\$$ had to be increased to 5 bn and finally to $7.5 \mathrm{bn},{ }^{62}$ i. e. by a factor of five within a time frame of a mere four weeks (sic!).

60 See also Móczár, J., op. cit., 322, joining Solow and Blinder in his criticism.

61 Frydman, R./Goldberg, M.D.: Imperfect Knowledge Economics: Exchange Rates and Risk, Princeton, NJ, 2007.

62 Wall Street Journal Europe of 21.02. 2009. 
In addition, from the policy-makers' perspective the reliance on the output of the most fashionable segments in contemporary academia is becoming less and less a must. On the contrary, this output is often seen as bearing no relationship to the real world issues, which confront decision-makers. The analytical language used is unduly complex, while the conclusions apply only under very restrictive assumptions, which usually do not hold in real world scenarios. Therefore their willingness to fund, and even to employ, persons coming from what is often seen as an overly self-confident, but also insufficiently emphatic guild, has manifestly been on the decrease. The proliferation of public policy and public administration programmes, the growing recruitment to top (non-analytical) positions of persons with qualifications other than economics - be that mathematics, political science or international relations -, and the spread of public administration research have created stiff competition for macroeconomists. For microeconomics, the challenge comes from the flourishing of business schools, which openly delineate their curricula from what is seen as too abstract and of little practical avail for the students.

These features have been already diagnosed a decade ago. ${ }^{63}$ For the "disconnection" between academic theory and the real world issues as well as the ensuing steady decline in what has increasingly become the predominant market segment - outside the self-reproduction of theoretical departments -, the self-interpretation of the profession and the ensuing standardisation were to blame. "Product differentiation", i.e. adjusting to the relevant market segment, took place mostly, though by no means exclusively, outside the walls of the traditional departments - namely in those few programmes, where policy components, sectoral specificities, environmental issues or "heterodox" approaches such as public choice have come to the fore. This is all the more surprising as the need for differentiating our product from those of others used to be an age-old insight both in academia and business. It is hardly by chance that Hayek always claimed that it is the trial and error nature of the market, which makes it superior to any other arrangements that aim to replace its inherent feature of catallaxy with optimising or planning procedures. ${ }^{64}$

With the advancement of the natural sciences, many axiomatic items in mainstream economics have become subject to criticism. Empirical evidence for in- 
stance is indicative of the irrelevance of the symmetry axiom in terms of loss and gain, but also of other "objective" quantitative measures for assessing economic attainment by the representative agent. ${ }^{65}$ Other analyses have experimentally proven the overwhelming relevance of the bounded rationality insight of Herbert Simon $^{66}$ for basically all human actions and far not only in the emotional field. ${ }^{67}$ More recent research has found not just lack of evidence, but positive/empirical counter-evidence for the occurrence of maximising behaviour, particularly in areas where the intuitive would tell us this to be the case, such as in firms and in professional sports. ${ }^{68}$

It has long been argued, that the "butterfly effect" discovered by the mathematician and meteorologist Edward Lorenz, ${ }^{69}$ which means that small changes can trigger enormous modifications in unexpected remote parts of a complex system, is of major relevance for the understanding of economic systems. The financial crises of the 1997-99 period provided ample evidence for the practical and analytical significance of this and related insights. If this holds, sticking rigidly to the arsenal of Newtonian physics and the related mathematics may prove to be positively misleading for the economist, since the fundamental analytical assumptions of the analysis simply do not hold. In the frontrunner natural sciences, such as biology and nuclear physics, the cited insights count among the platitudes for decades.

The fundamental methodological consequences of the above are at least twofold. First, the question emerges to what extent - if at all - complex systems actually lend themselves to mathematical modelling following the Descartian-Newtonian path of simplifying assumptions. The second issue is how far axiomatic thinking can go without relying on the feedback coming from sister disciplines. In the past decades research paradigms, which attempt to integrate fundamentally changed insights and the related uncertainty into economic analysis, have been gaining currency. Let us underscore: we are not referring to the heterodox approaches

65 Kahneman, D./Krueger, A.: Developments in the Measurement of Subjective Well-Being, in: Journal of Economic Perspectives, 20/1 (2006), 3-24.

66 Simon, H.: Models of Man: Social and Rational, New York, 1957.

67 Selten, R.: Features of Empirically Observed Bounded Rationality, in: European Economic Review, 42/2-3 (1998), 413-436.

68 Romer, D.: Do Firms Maximize? Evidence from Professional Football, in: Journal of Political Economy, 114/2 (2006), 340-365.

69 Lorenz, E.: Deterministic Nonperiodic Flow, in: Journal of the Atmospheric Science, 20/2 (1963), 130141. 
and the surviving quasi-marginal schools, such as neo-Marxism, post-structuralism or old-style institutionalism despite their obvious presence and sometimes remarkable partial findings. What we find decisive for the future of the discipline is the reverse stream, i.e. the penetration of fundamentally different insights from the natural sciences and mathematics into what seemed to be the closed fortress of mainstream economic analysis. If society can be modelled in an imperfect manner only, showing non-linear feedbacks, turbulence is likely to be a major feature - consequently chaotic outcomes become as probable as in the case of meteorological observations. For this reason it is conceivable that attempts to adopt chaos theory for understanding economic phenomena ${ }^{70}$ will show the road for future analyses.

It is perhaps telling that the most receptive audience to this reverse stream could be found not in the ivory towers of academic economics departments, but among persons who are closest to the most complex economic phenomena, i.e. those dealing with the capital markets. Very few have properly understood the depth of the quibble of Alan Greenspan in 1996 of the "irrational exuberance of financial markets" - a point which has since become a journalistic platitude. Likewise, George Soros in one of his recent books - inspired by a combination of philosophical and psychological insights, financial market instinct and decades of experience - also questions the omnipresence and omnipotence of rationality, which is postulated and propagated by formal economic models, most notably by the dominant theory of efficient markets. ${ }^{71}$

\section{A Gradual Penetration of Mainstream by Insights from the Fringes?}

The widespread presence of non-rational behaviour, lack of symmetries and incalculability all call for the reassessment of our analytical methods. Moreover, if the above cited general insight about the limitations of reductionism as a method holds, the axiomatic nature of the up until recently unquestionable methodological focus, both per se and in its current form, can no longer be taken for granted. And the more we still consider - on grounds of tradition and self-esteem - methodology as a formative component of the discipline, the more it becomes not just commendable but compelling for economic analysis to reflect 
on the advances made in the natural sciences. This holds for at least three major planes: a) the axioms, i. e. the limited use of Robinsons following arbitrary, predetermined choices or unconditional maximizing behaviour disregarding competing considerations $;{ }^{72}$ b) modelling via deterministic procedures yielding exact quantitative outcomes; c) interpretations - within the model and for the real world applications (if any) alike, including their predictive power.

It tells a great deal about the new standards of the profession that the exposition of neuro-economics was allotted the distinguished Hahn Lecture for the Royal Economic Society in $2006,{ }^{73}$ where the presence of behavioural economics in preceding years could best qualify as a trifle. This line of research is following the traditional microeconomic interest in its search for elementary and observable foundations for individual economic decisions. At the same time it firmly rejects the basic feature of neoclassical theory, originating with Pareto and Jevons, of taking the mind and thus the process of micro decisions as a black box. Neuro-economics aims to create a microeconomic theory of how the brain works, and support it with empirical, experimental observation. It has found that conventional postulates on which rational choice models are built do work in "life and death" decisions (food, sex, danger). In more complex situations however, the preference for immediacy and nonlinear weighting of probabilities occur. Finally, in a third group of observations, preferences tend to be state dependent - unless they relate to biological state or neural system. This research agenda indicates that a more complex and also more robust modelling of human choices and thereby of the economy is in the making.

Furthermore in a number of areas, approaches that tended to be marginalised by mainstream orthodoxy, are regaining their standing. For instance the Asian financial crisis rehabilitated, at least to some degree, old institutionalism through its focus on corporate governance - signalled by the fact that the Ely Lecture of the American Economic Association was devoted to this issue. ${ }^{74}$ The already cited insights of Simon, Kahneman and Selten have long been in use in behavioural finance. With the collapse of the Soviet Empire, but also owing to the limited success of adjustment programs of emerging markets, historically in-

72 Thaler, R.: From homo oeconomicus to homo sapiens, in: Journal of Economic Perspectives, 14/1 (2000), 133-141.

73 Camerer, C.F.: Neuroeconomics: Using Neuroscience to Make Economic Predictions, in: The Economic Journal, 117/519 (2007), C26-C42.

74 Williamson, O.: The Economics of Governance, in: American Economic Review, 95/2-3 (2005), 1-18. 
formed analyses, such as the oeuvre of Douglass North ${ }^{75}$ and David Landes ${ }^{76}$ returned to the main stage. Likewise the broad law and economics approach, originating with the Freiburg school in Germany, but rediscovered and broadened by scholars at Berkeley, Yale, Harvard as well as other leading schools, seems to have gained in significance. In the practice of international agencies, this approach revived during the study of the limitations of transplants in improving the performance of emerging economies. ${ }^{77}$ The articles by Shleifer and Glaeser $^{78}$ and by Djankov et al. ${ }^{79}$ on the crucial role of institutions in explaining economic outcomes were published in the top journals of the profession. 15 years later, John Vickers of Oxford reports in the February issue of Economic Jour$n a l^{80}$ of a major research project on the issue with its output showing up in handbooks and all major top journals of the profession - and the same issue of $E J$ carrying a contribution from an US Supreme Court judge on the interaction of the two disciplines and its ramifications for judicial practice. Lines of research that seemed esoteric for the technicist orthodoxy, such as the role of inherited legal institutions among the factors of development ${ }^{81}$ or the role of Islam-related legislations on property rights and growth ${ }^{82}$, figure prominently on the pages of top journals. Importantly, these new, historically informed analyses receive formal support from studies on the implications of Islam for democracy and market economy. ${ }^{83}$ Still, it is hard to overlook the fact that these novelties are published only upon two conditions: a) if they come from people from within the guild-

75 North, D. C.: Understanding the Process of Economic Change, Princeton, NJ, 2005.

76 Landes, D.: Why Europe and the West? Why not China?, in: Journal of Economic Perspectives, 20/2 (2006), 3-22.

77 Berkowitz, D./Pistor, K./Richard, J.F.: Economic Development, Legality and the Transplant Effect, in: European Economic Review, 47/1 (2003), 165-195.

78 Shleifer, A./Glaeser, E.: The Rise of the Regulatory State, in: Journal of Economic Literature, 41/2 (2003), 401-425.

79 Djankov, S. et al.: Courts, in: Quarterly Journal of Economics, 118/2 (2003), 453-517.

80 Vickers, J.: Economic Rules of Law - Introduction, in: The Economic Journal, 119/535 (2009), F122.

81 Levine, R.: Law, Endowments and Property Rights, in: Journal of Economic Perspectives, 19/3 (2005), 61-88; Shleifer, A./Lopez-de-Silanes, F./Laporta, R.: The Economic Consequences of Legal Origins, in: Journal of Economic Literature, 46/2 (2008), 285-332.

82 Kuran, T.: Why the Middle East is Economically Underdeveloped: Historical Mechanisms of Institutional Stagnation, in: Journal of Economic Perspectives, 18/3 (2004), 71-90.

83 Borooah, V./Paldam, M.: Why is the World Short of Democracy?, in: European Journal of Political Economy, 23/3 (2007), 582-604. Both sources underscore the distinction between a religious majority of one sort or another - which constitutes no barrier to catallaxy as such -, and Islam as a state religion, i. e. the backbone of the legal and political order, as in the cases of Sudan or Iran for example, but not in Malaysia or Morocco. 
meaning the top US schools, and b) if they are presented in a formalised language, again irrespective of the originality of the insight, or whether or not the point could be also conveyed through verbal means.

To sum up: while the technicist orthodoxy still dominates promotion in the academia and most of the leading journals, this is probably due to the usual quarter of a century delay in the implementation of any insights, already lucidly observed by John M. Keynes, ${ }^{84}$ rather than to any of the "best practices" regardless of how these are defined. We have thus described a double challenge for the profession. From the outside, both the market - in terms of employment and funding - and the evolution of the natural sciences are calling for structural changes. These have indeed materialised during the current decade, although in a very incremental and limited fashion. From the inside, as we have seen, similar challenges emerged in response to interaction with other disciplines and in facing limited successes in predicting ${ }^{85}$, interpreting and managing practical matters.

In the light of the Nobel Prizes awarded to numerous personalities working on other than mainstream fields, such as Thomas Schelling - author of a bestseller in international security relations -, Daniel Kahneman - regularly publishing in journals of psychology - or the historian Douglass North, the new developments all point to an important direction. This is the inadmissibility of confining economics to a single method of analysis only, void of its own subject matter. Not only because mathematics and philosophy have already taken these functions over the centuries. But rather because for these scholars have been working on such diverse fields, still covering a common ground. They were all winning the Nobel Prize in Economics - not in any other area - due to this commonality, indeed. It was their common ground which is demonstrably their subject of analysis. Namely: how wealth creation and accumulation - though not necessarily maximisation - take place and how the related social choices are made; what are the rules of repeated games - i.e. institutions -; and through what methods we can understand these, rather than any other issue.

The more the economics profession is able to interpret itself with a degree of self-confidence that emanates, inter alia, from its common ground, common traditions, and common subjects, the more we shall be able to open up to col-

84 Keynes, J.M.: A kamat, a foglalkoztatás és a pénz általános elmélete [General Theory of Interest, Employment and Money, Budapest, 1965 (first published 1936), $407 \mathrm{f}$.

85 As it is known, the ability to produce sound predictions is perhaps the only measure of academic value on which followers of Friedman and Samuelson would immediately come to an agreement. 
leagues working in other disciplines. This should not be seen as a new trend or a basic innovation. In fact, besides the examples cited above, we may mention Paul Krugman and Anthony Venables ${ }^{86}$ as representatives of the established mainstream who focus on new economic geography and work on the reinvention of space, a dimension also lost during the period of formalisation revolution. As their oeuvre shows, being open does not imply giving up either our angle of analysis or the specific analytical methods including modelling.

If a less orthodox approach prevails, then the work of constitutional political economy scholars, such as James Buchanan, ${ }^{87}$ or the rules versus discretion approach of Kydland and Prescott, ${ }^{88}$ which directly relate to the political process in which economic decisions are made, should become part and parcel of the new understanding of the discipline. If this occurs, then being practically relevant might no longer be counted as a mortal sin for an academic. The insights of the authors mentioned, after having been translated into independent central banks and fiscal rules, sometimes anchored in the constitutions, have already shown in a pioneering way how to proceed in the future.

Policy-oriented studies, though less appreciated in the past few decades, have traditionally figured high on the agenda of economic analysis. From such classic examples as Ricardo's fight against protective farm tariffs to more recent cases such as the Nobel lecture of Ed Prescott, ${ }^{89}$ focusing on the need for long term strategy rather than discretionary micromanagement, policy induced issues never entirely disappeared from the stage. Certainly, it would be wrong to suggest even to tolerate a regress into shallow public debates over individual policy measures. Therefore, if complex issues are raised, such as pension reforms, regulation of the information technology markets (internet trade), international financial architecture or poverty reduction, it would be next to impossible to disregard analyses coming from mainstream theory. For instance, quantitative testing of competing theories on a number of specifications ${ }^{90}$ do not lend support to the idea, emerging

Krugman, P./Venables, A.: Globalization and the Inequality of nations, in: Quarterly Journal of Economics, 110/4 (1995), 857-880.

87 Buchanan, J.: Constitutional Economics, Oxford, 1991.

88 Kydland, F./Prescott, E. C.: Rules Rather than Discretion: the Inconsistency of Optimal Plans, in: Journal of Political Economy, 85/3 (1977), 473-492.

89 Prescott, E. C.: The Transformation of Macroeconomic Policy and Research. Nobel Lecture, in: Journal of Political Economy, 114/2 (2006), 203-235.

90 Paldam, M./Gundlach, E.: Two Views on Institutions and Development: the Grand Transition versus the Primacy of Institutions, in: Kyklos, 61/1 (2008), 65-100. 
as a majority view in recent literature, that "primacy of institutions" can and should be taken as a given in explaining long-term economic growth in the $20^{\text {th }}$ century. Thus it is not just the traditional reference to "culture" or "institutions" that is needed, but well-specified propositions about which institutions matter, how, when and for whom. Such an approach is likely to yield insights, which help to operationalise the practical meaning of abstract economic models and concepts. If for no other reasons, side conditions for implementing the optimal economic insights - whatever these might be - by necessity should include the understanding of the workings of social groups, legal norms, state and non-state actors as well as transnationalisation in its complexity.

\section{Coping with Complexity - the Basic Challenge for the Future}

For understanding of complex outcomes that result from a variety of interactive processes and are shaped by various, often contradicting rationalities, developing a comprehensive analytical framework and a nuanced interpretation has become a must. Examples include the clash between individual and collective rationality, abundantly addressed in the literature on policy reform, short and long-term considerations, as formulated in the idea of time inconsistency, or the age-old conflict between media impact and economic efficiency. It is telling, that much in line with the academic argumentation quoted earlier, an iconic practitioner, Alan Greenspan also considers the elegant models in use "too simple" to cope with the complex and often contradictory signals originating from market players, be that euphoria or panic. ${ }^{91}$ In short, he intuitively re-states the lack of symmetry thesis elaborated above, and contributes to the line of the criticism about overusing the concept of rationality and de-emphasising the empirically observable in favour of technical elegance. This is in accordance with the insights of physicists about the probability of intuitively incorporating factors triggering chaos, although this is more of an art than science in the narrow sense.

A broad ex post survey and academic analysis of the reasons for the eruption of the sub-prime crisis has indicated the focal role of interaction between regulatory failure and the "fatal conceit", i. e. of blind faith of money managers in their ability to quantify and thus exclude ex ante any financial risks of any magnitude. ${ }^{92}$ This misbelief could well have been discredited by the LTCM collapse in

91 Greenspan, A.: We Will Never Have a Perfect Model of Risk, in: Financial Times of 16. 03. 2008.

92 Győrffy, D.: A Brave New World in America: Dreams of the State and Reality of Crisis, in: Public Finance Quarterly, 54/2 (2009), forthcoming. 
1998. However, both shared beliefs of bank managers in the "end of the business cycle", and the science appeal of modelling, suggesting the infinite ability to manage and control any risk at any time on any markets, acted in a mutually reinforcing manner until the collapse could no longer be averted. In a similar vein, Princeton professor Shin also warns against the ubiquitous calls for stiffer regulation noting that the collapse of Northern Rock was triggered by a maturity mismatch due to universal de-leveraging. ${ }^{93}$ And "financial regulation that relies on risk-weighted capital requirements is powerless against such risks". As we have shown, the latter was an immediate consequence of the exclusive reliance of regulators on the most fashionable models offered by the profession.

Other analysts complement these insights with a traditional feature of economic analysis, namely the relevance of incentives, including incentives of the regulators not to intervene at one point, and positively creating inducement for what has proven to be misbehaviour by eliminating or watering down prudential (conventional) considerations. ${ }^{94}$ This is anything but a systemic failure, it is a feature of the system we need to live with, and countervail by "guarding the guardians" as the Romans put it.

A more attentive stance towards other disciplines is now in the self-interest of economics if it wants to escape the very real danger of being relegated to a socially and academically irrelevant, self-referential intellectual activity. Being attentive and receptive to the findings of others is part and parcel of the professional minimum. While we are aware of the substantial difference between our normative vision and reality, microincentives may move economists and economics departments alike to a less assertive and more co-operative stance than it had been the case during the second half of the $20^{\text {th }}$ century. In the words of the then-President of the Royal Economic Society:

"Since there is no kind of economic truth, which holds the key to all economic problems, no pure economic theory is immune to changes in social values or current policy problems. The scope and method of our discipline needs at all time be defined in relation to social problems, which give purpose to it, and there is room for more than one progressive research program in operation at the same time." 95 Journal of Economic Perspectives, 231 (2009), 101-119, here 101.

94 Swan, P.: The Political Economy of the Subprime Crisis: Why Subprime Was so Attractive to its Creators, in: European Journal of Political Economy, 25/1 (2009), forthcoming (already available online).

Deane, $P$., op. cit., $11 \mathrm{f}$. 
In his presidential address to the American Economic Association, Nobel Prize winner George Akerlof goes even further. ${ }^{96}$ Referring to the advances made in the natural sciences related to human behaviour and organism, he calls for $a$ revision of the exclusiveness of the positive economics paradigm, in which statistical testing is everything, while studying cases and intentions is discarded as anecdotal evidence. If studying a single DNS molecule can foretell the entire story of the evolution of an individual, he claims that the study of norms, intentions and motivations can be no longer excluded from the arsenal of interpreting economic phenomena. ${ }^{97}$ Moreover, when nonlinear dynamics become important, as in contemporary physics, mathematics, biology, chemistry, meteorology and even in financial economics ${ }^{98}$, predictive power alone, in the usual sense of foretelling the future in exact quantitative terms, can no longer serve as the measure of what is "true science". At this point one may wonder if a new paradigm in full of its arsenal should be forthcoming in a fully elaborate form. Or alternatively: allowing for more diversity in terms of trials and errors, in terms of methodology, and in terms of experimentation - à la Vernon Smith, Richard Selten and Danny Kahnemann - should be allowed to flourish until the historians of economic thought can retrospectively assess if any of those have proven to be other than pure fashion, i. e. the actual mainstream of lasting findings, seen from the angle of tomorrow.

\section{Conclusions}

Summing up our argument, despite our normative undercurrent, in terms of forecast we may follow Colander et al. ${ }^{99}$ that a Kuhnian paradigm shift in the orthodoxy of the current mainstream is still unlikely, although an evolutionary change is clearly perceptible in the literature we surveyed. As they rightly observe $\mathrm{e}^{100}$

96 Akerlof, G. A.: The Missing Motivation in Macroeconomics, in: American Economic Review, 97/1 (2007), 5-36, here 27-29.

97 In a way this echoes the insight of Hayek, F.A.: The Counter-Revolution, op. cit., 77-92, that the tendency to objectivism often translates to study what is measurable, rather than what is relevant, which means putting numbers on issues that have no real world meaning and can be justified only by data availability or computational convenience. Let us add: the popularity of composite indices without a positive dimension, such as generalised corruption indices or the aggregate measure of human development, are beautiful cases to the point.

98 Götz, G.: A pillangó effektus - a káosz felfedezése a meteorológiában [The Butterfly Effect - Discovering Chaos in Metheorology], in: Fizikai Szemle, 43/12 (1993), 487-490.

99 Colander, D./Holt. R./Barkeley-Rosser, J.: Live and Dead Issues in the Methodology of Economics, in: Journal of Post-Keynesian Economics, 30/2 (2007), 303-312.

100 Ibid., 308. 
cumulative and evolutionary change must come from within. As our analysis has tried to demonstrate, it is already well in the making. The decoration of one of the most outspoken and reality/policy oriented representatives of the guild, Paul Krugman, in 2008 might well point in this direction. Likewise, formative personalities of the mainstream also talk about this change being already in the making. Gary Becker for instance claims: "While the economic approach to behavior builds on the theory of individual choice, it is not mainly concerned with individuals. It uses theory at the micro level as a powerful tool to derive implications at the group or macro level." ${ }^{101}$ Furthermore, he states that "a close relation between theory and empirical testing helps prevent both theoretical analyses and empirical research to become sterile" ${ }^{\text {102 }}$. Similarly, Robert Solow, in his recent addendum to his Nobel autobiography claims, that economic growth theory "may be coming back to a more historical view"103, a trend this contribution also tried to document.

Should our assessment hold, at least in part, the excessive methodological focus, which led to the exclusionism and intellectual arrogance of the past two decades, is likely to be overcome, in terms of promotion, academic appreciation and access to major forums alike. Instead, a number of traditional/conventional/across the board used academic measurements of success, which include the sustainability of new findings and their applicability on real world issues, will be regaining their traditional significance.

The combination of formal/quantitative and interpretative/qualitative approaches, joining institutionally informed and statistical analyses, no longer counts as a rarity. It helps answering such non-trivial and otherwise only emotionally approachable questions like those of post-communist societies, or the local ownership of reforms versus EU anchoring or IMF advice. If the rather ambiguous and complex answers provided in these sources survive a decade, they will qualify as sound pieces of science, even if later research may qualify or even disprove them on the basis of new evidence or new methodology. At the end of the day such results will undoubtedly mark the irreversible return of economics into the row of established sciences, natural and social alike.

101 Becker, G.: The Economic Way, op. cit., 15.

102 Ibid.

103 Solow, R. M.: Autobiography. Addendum, May 2005, online at http://nobelprize.org/nobel_prizes/econ omics/laureates/1987/solow-autobio.html. 
What is the value added of this tour d'horizon for the future of economic analysis? There are at least three major lessons. First: the traditional delineation between hard facts and soft interpretations can be no longer sustained, probably not even in introductory textbooks. If - as by Kuhn - a new paradigm is like a new pair of glasses, allowing you to see the same in a very different light with different implications, furthermore if the way of observation influences the observed object - as in quantum physics -, the two issues become Siamese twins and can not be separated.

Second: methodological pluralism must be taken as a given already, and its open acknowledgement is probably just a matter of time. Since economics receives impetus from such a wide variety of disciplines, each formulated according to its own specific paradigm, there is no hope, even in the abstract or in the future, for the re-emergence of any $19^{\text {th }}$ century type of grand theory of social science or even of economics proper. It is difficult to imagine that the study of the DNS molecule and the study of the history of constitutions could or should be conducted within the same paradigm. Thus interaction with one or the other might take place side by side, rather than in a seemingly integrated, but on the ground eclectic and incoherent framework. Once again: it is the subject matter-conditions and mechanisms of wealth creation, distribution and accumulation - rather than any particular methodology of analysis, which will remain the unifying principle. This development is in fact quite in line with developments in contemporary physics.

It is reassuring to find, that not long after floating the basic arguments of this paper in Hungarian, the 2002 Nobel Prize winner, Vernon Smith, advanced similar normative suggestions in his assessment of the future of the economics profession. ${ }^{104} \mathrm{He}$ also highlights the dangers that follow from the extreme simplifications of the neoclassical approach, which uses axioms for behavioural norms that are positively contradictory to the observations in societies and experimental research of human behaviour in the laboratories. These include selfishness complete lack of altruistic, aesthetic and playful motives -, lack of voluntary cooperation, perfect foresight, the ensuing full rationality of expectations, ability to assess future financial outcomes, and similar ability to foresee and neutralise failures of regulators, which more often than not, lie at the root of crises. This translates into a much broader interpretation of what is or is not covered by aca-

104 Smith, $V$ : Die nächste Blase wird schon vorbereitet, Interview in: Frankfurter Allgemeine Zeitung of 11.07. 2008. 
demic economics, with a due emphasis on the plurality of approaches and methodologies, figuring high on the agenda of the most recent assessment of the field in the authoritative organ of the American Economic Association. ${ }^{105}$

Third, this contribution hopefully contributed to the more nuanced understanding of how advances in the contemporary natural sciences could and should be incorporated into economic analysis. Our basic contention is the need for organic interaction, rather than mere interfaces on the surface. While the subject matter of economic analysis calls for interaction with a variety of sister disciplines, in so doing the nature of the subject matter, rather than the mere availability of an analytical tool or formalisation possibilities, i. e. technical convenience, should be the prime maxim. And while "economic imperialism" of the Becker type might still be one plane of the interaction, this should definitely and urgently be complemented by the incorporation of new, perplexing insights of other sciences, even if these undermine previously axiomatic views such as rationality or the symmetry of loss and gain.

105 Backhouse, R./Medema, S.: Retrospectives: on the Definition of Economics, in: Journal of Economic Perspectives, 23/1 (2009), 221-233. 